\title{
Ruminal Degradability and Summative Models Evaluation for Total Digestible Nutrients Prediction of Some Forages and Byproducts in Goats
}

\author{
Oswaldo Rosendo, ${ }^{1}$ Luis Freitez, ${ }^{1}$ and Rafael López ${ }^{2}$ \\ ${ }^{1}$ Departament of Animal Nutrition and Forages, Decanato de Ciencias Veterinarias, Universidad Centroccidental \\ Lisandro Alvarado, Tarabana 3001, Venezuela \\ ${ }^{2}$ Universidad del Zulia, Maracaibo 4005, Venezuela
}

Correspondence should be addressed to Oswaldo Rosendo; orosendo@ucla.edu.ve

Received 28 February 2013; Accepted 28 March 2013

Academic Editors: L. Badinga and R. Gamble

Copyright ( 2013 Oswaldo Rosendo et al. This is an open access article distributed under the Creative Commons Attribution License, which permits unrestricted use, distribution, and reproduction in any medium, provided the original work is properly cited.

In in vitro true dry matter degradability (IVTDMD), in situ dry matter degradability, and neutral detergent fiber degradability, both in vitro (IVNDFD) and in situ (ISNDFD) techniques were used with crossbred goats to determine dry matter and neutral detergent fiber (NDF) ruminal degradability in eight forages and four industrial byproducts. Total digestible nutrients (TDN) content obtained with five different summative models (summative equations) were studied to compare the precision of estimates. All these models included digestible fractions of crude protein, ether extract, and nonfiber carbohydrates that were calculated from chemical composition, but digestible NDF (dNDF) was obtained from IVNDFD (IVdNDF), ISNDFD (ISdNDF), or by using the Surface Law approach. On the basis of the coefficient of determination $\left(R^{2}\right)$ of the simple lineal regression of predicted TDN $(y$ axes) and observed IVTDMD ( $x$-axes), the precision of models was tested. The predicted TDN by the National Research Council model exclusively based on chemical composition only explains up to $41 \%$ of observed IVTDMD values, whereas the model based on IVdNDF had a high precision (96\%) to predict TDN from forage and byproducts fiber when used in goats.

\section{Introduction}

Currently, feeding standards for ruminants are based on predictions of total digestible nutrients (TDN), digestible energy (DE), metabolizable energy (ME), and/or net energy (NE) from the in vitro digestibility determinations of organic matter (IVOMD) and/or chemical composition [1-3]. However, there are no energy prediction equations created and validated specifically for goats. The tabulated energy values in the National Research Council (NRC) for small ruminants [4] are based on measurements of TDN in vivo, most of which were carried out some years ago, in sheep. Therefore, the prediction of TDN is justified to increase the accuracy of the values used in ration formulation and ultimately reduce the risks of energy imbalances in dairy goats.

There are a number of prediction equations in ruminants, from simple regression equations [5-7] to equations called "multiple" or "summative" $[8,9]$. However, it is recommended to evaluate the validity of any prediction equation by taking into account the evaluation of digestibility and chemical composition of local feedstuff [2].

The summative equation developed by Weiss et al. [9] and later adopted by the NRC (2001) of dairy cattle [3] calculated each digestible feed fraction and among these, the potentially digestible NDF ( $\mathrm{dNDF}$ ) by a subecuación which is based on the nonlinear relationship between NDF and lignin. This relationship implies that lignin has a physical effect, besides the chemical effect of protection against digestion of structural carbohydrates, making the NDF indigestible $[10,11]$. Theoretically, the indigestible NDF is proportional according to the surface law to two-thirds of the surface area represented by the mass of lignin, but inversely proportional to the surface of NDF $[10,12]$. However, the prediction of the energy value can be a problem for tropical forages and 
TABLE 1: Chemical composition of evaluated feed.

\begin{tabular}{|c|c|c|c|c|c|c|c|c|c|}
\hline \multirow{2}{*}{ Feed } & \multicolumn{9}{|c|}{ DM \% } \\
\hline & $\mathrm{OM}$ & $\mathrm{CP}$ & $\mathrm{EE}$ & $\mathrm{NDF}$ & $\mathrm{ADF}$ & $\mathrm{L}$ & NDICP & ADICP & $\mathrm{NFC}^{1}$ \\
\hline Discarded corn & 92.4 & 10.3 & 2.4 & 57.3 & 21.0 & 6.7 & 5.8 & 3.3 & 28.2 \\
\hline Discarded sorghum & 93.1 & 7.9 & 2.2 & 43.9 & 23.1 & 6.8 & 5.5 & 2.1 & 44.5 \\
\hline Discarded sesame & 73.7 & 5.2 & 13.6 & 32.8 & 50.8 & 6.8 & 4.9 & 2.6 & 26.9 \\
\hline Citrus pulp & 94.9 & 6.1 & 3.1 & 25.9 & 28.9 & 6.4 & 1.2 & 1.3 & 61.0 \\
\hline Sugar cane, whole plant, 6 months & 96.3 & 4.3 & 0.8 & 63.9 & 38.6 & 6.5 & 3.2 & 2.0 & 30.5 \\
\hline Forage sorghum & 93.1 & 5.3 & 0.9 & 68.9 & 46.4 & 9.0 & 5.5 & 3.3 & 23.5 \\
\hline Bermudagrass & 90.3 & 8.0 & 1.0 & 77.9 & 46.5 & 6.6 & 6.0 & 2.6 & 9.3 \\
\hline Brachiaria & 95.8 & 7.1 & 1.6 & 77.0 & 41.9 & 8.7 & 5.7 & 2.9 & 15.8 \\
\hline King grass & 93.1 & 5.8 & 1.6 & 73.0 & 47.0 & 5.9 & 3.9 & 2.2 & 16.7 \\
\hline Kikuyu grass & 85.2 & 7.4 & 0.8 & 73.2 & 42.8 & 7.8 & 5.4 & 2.0 & 9.1 \\
\hline Guinea grass & 87.1 & 12.7 & 1.9 & 71.6 & 46.3 & 8.3 & 7.1 & 1.7 & 8.0 \\
\hline Stargrass, 20 days & 90.8 & 17.7 & 1.4 & 70.5 & 40.0 & 6.1 & 8.8 & 1.8 & 9.9 \\
\hline
\end{tabular}

${ }^{1} \mathrm{NFC}, \%: 100-[\mathrm{CP} \%+(\mathrm{NDF} \%$ - NDICP\%) + EE\% + Ash\%], where, NDICP: neutral detergent insoluble crude protein, EE: ether extract.

fibrous feed, due to the high variability in NDF digestibility (NDFD), as well as to the low predictive power that the chemical composition has on NDFD [13]. This limitation could be overcome in goats if the potentially digestible neutral detergent fiber fraction is determined by methods in situ or in vitro.

Adapting dairy goat diets to high levels of fiber is well documented [14-16]. However, the evaluation of ruminal degradability, in situ or in vitro, in forages and byproducts is rare when it comes to goats. Although forage DM and NDF digestibility can be similar for cattle and goats under maintenance [17]; the equation of NRC (2001) [3] should not be extrapolated to dairy goats, without prior evaluation, due to known differences that occur between these two species in their level of intake, passage rate, and retention time [16-18].

The present study was aimed to determine the ruminal degradability of DM and NDF, both in vitro and in situ, on forages and fibrous byproducts using ruminal liquor of goats and second to evaluate the usefulness of ruminal degradability of fiber together with chemical composition to predict the TDN content. More specifically, different summative models that use digestible NDF fraction to predict TDN are evaluated.

\section{Materials and Methods}

Eight samples of forages and 4 byproducts were received at the laboratory of Animal Nutrition, College of Veterinary Science (University Lisandro Alvarado, Venezuela), for routine chemical analysis. Samples were selected based on obtaining sufficient variabilidad both in chemical composition and ruminal degradability. These samples were bermudagrass (Cynodon dactylon), stargrass (Cynodon nlemfuensis), guinea grass (Panicum maximum), king grass (Pennisetum purpureum, cv king grass), Kikuyu grass (Pennisetum clandestinum), Brachiaria (Brachiaria decumbens), forage sorghum (Sorghum bicolor), sugar cane and byproducts (discarded corn, Zea mays; discarded sorghum, sorghum vulgare; discarded sesame, Sesamum indicum and citrus pulp, citrus sp.). The crude protein content ranged from 5.2 to $10.3 \%$ in the byproducts and 4.3 to $17.7 \%$ in forages. While NDF content ranged from 25.9 to $77.9 \%$ with the highest values in forages and the lowest in byproducts. Meanwhile, the value of NDICP ranged from 1.2 to $5.8 \%$ in byproducts, while in forages ranged from 3.2 to $8.8 \%$ (Table 1 ).

2.1. Chemical Analyzes. The samples were dried at $100^{\circ} \mathrm{C}$ in an oven for $24 \mathrm{~h}$ to determine DM and then ground to $1 \mathrm{~mm}$ in a Wiley mill. Crude protein analysis, ADF, and Ash were performed according to the procedures of the Association of Official Chemical Analysis (AOAC) [19]. The NDF was determined using amylase and sodium sulfate [20]. Insoluble crude protein concentrations in ADF (ADICP) and NDF (NDICP) were analyzed according to procedures described by Licitra et al. [21]. Lignin (L) was quantified according to the sulfuric acid method [19]. The nonfiber carbohydrate concentration $(\mathrm{CNF})$ was calculated according to the following equation created by Nocek [20] and described by Van Soest et al. [22]:

$$
\begin{aligned}
& \text { NFC, } \% \\
& =100-[\mathrm{CP} \%+(\mathrm{NDF} \%-\mathrm{NDICP} \%)+\mathrm{EE} \%+\mathrm{Ash} \%],
\end{aligned}
$$

where NICP = Neutral detergent insoluble crude protein, EE $=$ ether extract.

2.2. Animals and Diet. Three nonlactating and non-pregnant cross-bred adult goats (mean body weight $=43 \mathrm{~kg}$ ) were fistulated in the rumen for using as donors of ruminal inoculum. Rubber cannulae ( $80 \mathrm{~g}$ weight, $35 \mathrm{~mm}$ internal diameter) were fabricated locally. The surgical technique consisted of a straight incision of equal length to the diameter of the cannula, without fasting, standing up during the surgical procedure [23]. The goats were used 12 weeks after surgery. Animals received a ration consisting of ad libitum bermudagrass hay $(7.7 \% \mathrm{CP}, 71.8 \% \mathrm{NDF}$, and $51.8 \% \mathrm{TDN}$, on 
dry basis) and $500 \mathrm{~g} /$ day of commercial supplement (18.4\% $\mathrm{CP}, 33.2 \% \mathrm{NDF}$, and $67.2 \% \mathrm{TDN}$, dry basis). The ration was provided during an adjustment period of 20 days.

2.3. In Vitro Incubations. One in vitro incubation was performed within each period $(n=3)$ of 21 days. On day 16 of each period, ruminal fluid was collected from the three goats after 15 days of adaptation to the diet, filtered through four layers of cheesecloth, mixed, and then carried out to the laboratory in a thermo. In vitro true DM digestibility (IVTDMD) and in vitro NDF digestibility (IVNDFD) was determined by the technique described by Van Soest et al. [24]. The in vitro system consisted of $50 \mathrm{~mL}$ polypropylene tubes (Fisher Scientific., USA) fitted with rubber stoppers and Bunsen valves (Fisher Scientific., USA). Incubations (Thelco Incubator, Precision Scientific., USA) were performed serially for 48 and 72 hours at $39^{\circ} \mathrm{C}$, for a total of 104 tubes ((twelve feed + blank $) \times 2$ tubes/sample $\times 2$ digestibilities $\times 2$ times), in each period. The tubes were gently shaken after incubation and at 6 hours intervals. Blank tubes (2) contained inoculum but no substrate was placed in each incubation time to estimate the amount of DM and NDF supplied by the inoculum in order to make corrections.

2.4. In Situ Incubations. Triplicate samples from each feed were placed and weighed $(3 \mathrm{~g})$ in nylon bags (Ankom) adjusted to a size of $10 \times 10 \mathrm{~cm}$. A total of 36 bags (twelve feed) were placed inside six pantyhose (6 feed/pantyhose). After immersed in distilled water at $39^{\circ} \mathrm{C}$ for $5 \mathrm{~min}$., a pantyhose was incubated in the rumen of each animal for $48 \mathrm{~h}$, at day 17 and 19 of each period. After, removal from the rumen, the bags were manually washed and dried for 48 hours at $60^{\circ} \mathrm{C}$.

2.5. Prediction of Total Digestible Nutrients. To estimate TDN at maintenance levels $\left(\mathrm{NDT}_{1 X}\right)$, the following equations from NRC (2001) [3] were used:

$$
\begin{gathered}
\mathrm{TDN}_{1 X}=\mathrm{dCP}+(\mathrm{dFA} * 2.25)+\mathrm{dNFC}+\mathrm{dNDF}-7, \\
\mathrm{dCP}(\text { forages })=\mathrm{CP} * \mathrm{EXP}\left(-1.2 *\left(\frac{\mathrm{ADICP}}{\mathrm{CP}}\right)\right) \\
\mathrm{dCP}(\text { concentrates })=\mathrm{CP} *\left(1-\left(0.4 *\left(\frac{\mathrm{ADICP}}{\mathrm{CP}}\right)\right)\right), \\
\mathrm{dFA}=1.00 *(\mathrm{EE}-1) \\
\mathrm{dNFC}=\mathrm{FAP} * 0.98 \\
*(100-(\text { Ash }+\mathrm{CP}+\mathrm{EE}+(\mathrm{NDF}-\mathrm{NDICP}))),
\end{gathered}
$$

where $\mathrm{TDN}_{1 X}=$ total digestible nutrients at intake levels of maintenance, $\mathrm{dCP}=$ digestible $\mathrm{CP}, \mathrm{dFA}=$ digestible fatty acids, $\mathrm{dNFC}=$ digestible nonfiber carbohydrates, $\mathrm{FAP}=$ Adjustment factor due to processing, ADICP = acid detergent insoluble crude protein, NDICP = neutral detergent insoluble crude protein (all expressed on a dry basis), and 7 represents endogenous losses of TDN. For all feed, FAP was 1.0 (Table 2.1 NRC 2001) in [3], while to calculated CP, byproducts were considered as concentrates.
The dNDF was calculated either from the IVNDFD (IVdNDF), ISNDFD (ISdNDF), or as a function of the surface law (LSdNDF) according to models that are explained below.

(a) LSdNDF (dNDF calculated based on the law of surface): based on the original equations of NRC (2001) [3] for calculating TDN exclusively from the chemical composition and wherein the $\mathrm{dNDF}$ is related to lignin concentration using a function based on the law of surface:

$$
\begin{aligned}
\mathrm{dNDF}= & 0.75 *((\mathrm{NDF}-\mathrm{NDICP})-L) \\
& *\left(1-\left(\frac{L}{(\mathrm{NDF}-\mathrm{NDICP})}\right) 0.667\right) .
\end{aligned}
$$

(b) IVdNDF (100\% of dNDF calculated from IVNDFD): this was based on using the technique of in vitro degradability during 48 hours of fermentation to calculate $\mathrm{dNDF}$ as an alternative manner proposed by NRC (2001) [3]:

$$
\operatorname{IVdNDF}=1.00 *\left(\frac{\text { IVNDFD }}{100}\right) * \mathrm{NDF}, \%
$$

(c) $0.75 \mathrm{IVdNDF} \quad(75 \%$ of $\mathrm{dNDF}$ calculated from IVNDFD): it was based on the computation of the dNDF using the technique of in vitro degradability for 48 hours of fermentation but multiplying by 0.75 (0.75IVdNDF), equivalent to the digestibility of potentially digestible NDF fraction according to the original equation of NRC (2001) [3]:

$$
0.75 \mathrm{IVdNDF}=0.75 *\left(\left(\frac{\mathrm{IVNDFD}}{100}\right) * \mathrm{NDF}, \%\right)
$$

(d) ISdNDF (100\% of dNDF calculated from ISNDFD), calculation of dNDF was based on in situ degradability of NDF during 48 hours of fermentation, thus

$$
\mathrm{ISdNDF}=1.00 *\left(\frac{\mathrm{ISNDFD}}{100}\right) * \mathrm{NDF}, \%
$$

(e) Rocha-Junior (dNDF calculated as Rocha-Junior): TDN was calculated using the NRC model [3] modified in Brazil by Rocha-Junior et al. [25] where dNDF equation was adjusted by nonlinear regression between observed and calculated values from subecuación of NRC (2001) [3]. The adjusted coefficient for $\mathrm{dNDF}$ is given by the following equation [25]:

$$
\begin{aligned}
\text { Adjusted } \mathrm{dNDF}= & 0.6232 *((\mathrm{NDF}-\mathrm{NDICP})-L) \\
& *\left(1-\left(\frac{L}{(\mathrm{NDF}-\mathrm{NDICP})}\right) 1.2258\right) .
\end{aligned}
$$

The rest of the equations to calculate $\mathrm{TDN}_{1 X}$ were similar to NRC (2001) [3]. 
2.6. Statistical Analysis. The study was analyzed as two different experiments (one in vitro and one in situ) with three replications for each. In the in vitro experiment, degradability ( 48 or $72 \mathrm{~h}$ ) of DM or NDF (Yijklm) of each feed (A) within each repetition $(R=3)$ was analyzed according to the following model:

$$
Y i j k=m+A i+R j+A R I J+e i j k
$$

In the in situ experiment, degradability of DM or NDF at $48 \mathrm{~h}($ Yijklm $)$ for each feed $(A)$ within each repeat $(R=3)$ was arranged by goat $(C=3)$, according to following model:

$$
Y i j k l m=m+A i+R j+C k+A R I J+A R C i j k+e i j k m .
$$

All the analyses were performed by using PROC GLM of SAS [26]. Averages for IVTDMD, IVNDFD, and ISNDFD were compared using the method of minimum significant differences $(P<0.05)$.

2.7. Quality Assessment of Summative Equations to Predict TDN. The evaluation of the accuracy of the model (summative equation) to estimate TDN was performed using the coefficient of determination $\left(R^{2}\right)$ of the linear regression of the predicted values of NDT for the model and observed values of IVTDMD, using PROC REG in SAS [26]. We chose this relationship (TDN and IVTDMD) to evaluate different summative equations for TDN, because in forages, the IVTDMD has been an acceptable predictor $\left(R^{2}=0.90\right)$ of the in vivo digestibility of DM in sheep [27]. Moreover, there are no distinct differences between sheep and goats, as for passage rate, retention time, and digestibility, when they are fed at maintenance conditions $[28,29]$.

\section{Results and Discussion}

3.1. In Vitro True Dry Matter Degradability and In Situ Dry Matter Degradability. In vitro true dry matter degradability and in situ dry matter degradabilityvalues of IVTDMD at 48 and $72 \mathrm{~h}$ of incubation are shown in Table 2, whereas ISDMD at $48 \mathrm{~h}$ are shown in Table 3 . With the exception of extensive degradation of MS in citrus pulp [30], the values of DM degradability were higher, intermediate, and lower for $72 \mathrm{~h}$ IVTDMD, and $48 \mathrm{~h}$ ISDMD, $48 \mathrm{~h}$ IVTDMD, respectively. DVIVMS values were higher at $72 \mathrm{~h}$, up to $15 \%$, to those found at $48 \mathrm{~h}$.

In forages, the IVTDMD at $48 \mathrm{~h}$ ranged from 51.4 to $80.8 \%$, with the lowest value for Brachiaria and the highest for the stargrass at 20 days of age $(P<0.05)$. High IVOMD values are often seen for preflowering stargrass with high levels of nitrogen fertilization [31]. However, this study was not specifically designed to compare the ruminal degradability among different forage species. In byproducts, IVTDMD at $48 \mathrm{~h}$ had the range of 68.1 to $77.4 \%$, with the highest value for discarded corn.

The chemical composition and IVTDMD of bermudagrass were consistent with those reported by other researchers [32]. The results suggest that those forages with higher CP and lower NDF concentration, as was the case of Guinea grass and stargrass, can be digested with greater efficiency by goats compared to bermudagrass. Therefore, the replacement of commercial bermuda hay, main source of forage for dairy goats in Venezuela, by other forage substitutes with greater DM degradability would maximize milk production in confined systems.

The ISDMD at $48 \mathrm{~h}$ was highly related to IVTDMD at $48 \mathrm{~h}\left(R^{2}=0.92\right)$ but with values up to $20 \%$ lower. Therefore, these results suggest that values of ISDMD at $48 \mathrm{~h}$ may underestimate in vivo DM digestibility.

\subsection{In Vitro and In Situ Neutral Detergent Fiber Degradability.} The values of IVNDFD at 48 and $72 \mathrm{~h}$ of incubation are shown in Table 2. An in vitro incubation period of $48 \mathrm{~h}$ may be appropriate to approach the in vivo digestibility values of NDF for dairy goats, because ruminal retention time for 10 hays of perennial grasses, including Bermuda, varied in the range of 24.9 to $53.3 \mathrm{~h}$ in goats under maintenance conditions [13].

In the present study, IVNDFD at $48 \mathrm{~h}$ ranged from 36.9 to $72.8 \%$ for forages with the highest value for stargrass and the lowest for Brachiaria, which explains the observed IVTDMD results. Thus, the lower NDF digestibility values observed were those forages with lower CP and higher ADICP contents; suggesting that microbial digestion of NDF was limited by the low availability of fermentable N. In goats, in vivo NDF digestibility of grass tends to reach values close to $70 \%$ when the $\mathrm{CP}$ content is $15 \%$ but only $60 \%$ or less when the concentration of CP lower than 10\% [33-35].

In the byproducts evaluated, the IVNDFD had the range from 4.8 to $80.5 \%$, with the lowest values for discarded sesame and discarded sorghum. The possible causes of high NDF indigestibility for discarded sesame may be associated with high fat and cutin contents $[4,11]$.

In general, the IVNDFD values at $48 \mathrm{~h}$ (Table 3 ) were lower than the values of ISNDFD at $48 \mathrm{~h}$, particularly for sesame discarded and citrus pulp; however, they were highly correlated. Thus, IVNDFD explained $94 \%$ of the variability in ISNDFD values (Figure 1). In cattle, Spanghero et al. [36] found a similar relationship, but on the contrary, the IVNDFD values were on average $19 \%$ higher than the effective in situ degradability of NDF. Robinson et al. also reported higher IVNDFD than ISNDFD values at $48 \mathrm{~h}$ [37].

3.3. Prediction of Total Digestible Nutrients. Some researchers have used IVTDMD or IVOMD values to calculate the values of TDN in forages and supplements when it comes to cattle $[38,39]$. The method of Tilley and Terry [40] as well as that of IVTDMD of Van Soest et al. [24] that replaces the 48 hours of pepsin incubation with extraction on neutraldetergent solution has a high correlation with the in vivo DM digestibility under maintenance conditions [27, 41].

The predicted TDN values obtained by evaluated summative equations are shown in Table 4 . Regression parameters between the predicted and observed values were calculated by using IVTDMD $48 \mathrm{~h}$ as the accepted observed values (Table 5). In this study, TDN values predicted, both by the 
TABLE 2: Means and standard errors of the in vitro true DM digestibility (IVTDMD) and in vitro NDF degradability (IVNDFD) at 48 and $72 \mathrm{~h}$ of incubation.

\begin{tabular}{|c|c|c|c|c|}
\hline Feed & IVTDMD-48 & IVTDMD-72 & IVNDFD-48 & IVNDFD-72 \\
\hline Discarded corn & $77.4^{\mathrm{cd}}$ & $81.6^{\mathrm{d}}$ & $60.6^{\mathrm{cd}}$ & $67.9^{c}$ \\
\hline Discarded sorghum & $73.2^{\mathrm{d}}$ & $79.1^{\mathrm{d}}$ & $39.0^{\mathrm{fg}}$ & $52.5^{\mathrm{d}}$ \\
\hline Discarded sesame & $68.1^{\mathrm{e}}$ & $70.3^{\mathrm{e}}$ & $4.8^{\mathrm{h}}$ & $9.5^{\mathrm{e}}$ \\
\hline Citrus pulp & $94.9^{\mathrm{a}}$ & $96.6^{\mathrm{a}}$ & $80.5^{\mathrm{a}}$ & $86.9^{\mathrm{a}}$ \\
\hline Sugar cane, whole plant, 6 months & $62.8^{\mathrm{f}}$ & $67.4^{\mathrm{ef}}$ & $41.8^{\mathrm{fg}}$ & $49.0^{\mathrm{d}}$ \\
\hline Forage sorghum & $58.2^{\mathrm{fg}}$ & $65.5^{\mathrm{f}}$ & $39.3^{\mathrm{fg}}$ & $50.0^{\mathrm{d}}$ \\
\hline Bermudagrass & $54.3^{\mathrm{g}}$ & $62.4^{\mathrm{fg}}$ & $41.4^{\mathrm{fg}}$ & $51.7^{\mathrm{d}}$ \\
\hline Brachiaria & $51.4^{\mathrm{g}}$ & $59.1^{\mathrm{g}}$ & $36.9^{g}$ & $46.8^{\mathrm{d}}$ \\
\hline King grass & $54.7^{\mathrm{g}}$ & $62.2^{\mathrm{fg}}$ & $38.0^{\mathrm{fg}}$ & $48.3^{\mathrm{d}}$ \\
\hline Kikuyu grass & $61.0^{\mathrm{f}}$ & $65.1^{\mathrm{f}}$ & $46.7^{\mathrm{ef}}$ & $52.4^{\mathrm{d}}$ \\
\hline Guinea grass & $75.2^{\mathrm{d}}$ & $80.8^{\mathrm{d}}$ & $65.6^{\mathrm{bc}}$ & $73.4^{\mathrm{bc}}$ \\
\hline Stargrass, 20 days & $80.8^{c}$ & $85.9^{\mathrm{c}}$ & $72.8^{\mathrm{ab}}$ & $80.1^{\mathrm{ab}}$ \\
\hline Standard error & 1.6 & 1.3 & 3.1 & 3.4 \\
\hline
\end{tabular}

a,b,c,d,e,f,g, means within a column with different superscripts differ $(P<0.05)$.

TABLE 3: Means and standard errors for in situ DM (ISDMD) and NDF degradability (ISNDFD) in nylon bag at $48 \mathrm{~h}$ of incubation.

\begin{tabular}{lcc}
\hline Feed & ISDMD-48 & ISNDFD-48 \\
\hline Discarded corn & $65.5^{\mathrm{d}}$ & $65.3^{\mathrm{b}}$ \\
Discarded sorghum & $67.3^{\mathrm{d}}$ & $52.6^{\mathrm{c}}$ \\
Discarded sesame & $57.0^{\mathrm{e}}$ & $22.1^{\mathrm{f}}$ \\
Citrus pulp & $96.4^{\mathrm{a}}$ & $92.0^{\mathrm{a}}$ \\
Sugar cane, whole plant, 6 months & $47.1^{\mathrm{fg}}$ & $42.1^{\mathrm{de}}$ \\
Forage sorghum & $47.5^{\mathrm{fg}}$ & $50.1^{\mathrm{c}}$ \\
Bermudagrass & $45.9^{\mathrm{fg}}$ & $46.6^{\mathrm{cd}}$ \\
Brachiaria & $58.4^{\mathrm{e}}$ & $49.3^{\mathrm{cd}}$ \\
King grass & $46.0^{\mathrm{fg}}$ & $46.1^{\mathrm{cd}}$ \\
Kikuyu grass & $49.1^{\mathrm{f}}$ & $54.6^{\mathrm{c}}$ \\
Guinea grass & $64.5^{\mathrm{d}}$ & $66.8^{\mathrm{b}}$ \\
Stargrass, 20 days & $67.7^{\mathrm{d}}$ & $69.8^{\mathrm{b}}$ \\
Standard error & 1.6 & $2.6^{2}$ \\
\hline
\end{tabular}

a,b,c,d,e,f,g, means within a column with different superscripts differ $(P<$ $0.05)$.

original equation of NRC dairy cattle [3], based exclusively on chemical composition (LSdNDF), as well as by the modified model of Rocha-Junior et al. [25], were less successful than those predicted by the equations that incorporate dNDF determined by either in vitro (IVNDFd) or in situ (ISNDFd) digestibility. Conversely, Magalhães et al. [42] found that models based on dNDF determined in vitro or in situ underestimated ME values for cattle when compared to the original NRC model based on chemical composition.

The NRC model to calculate TDN (LSdNDF) is based on the calculation of dNDF as a function of the surface law. While lignin raised to 0.66 (according to the law of surface) can explain most linear effects that $\mathrm{L}$ and FND have in dNDF, this does not include all possible determinants of dNDF [43]. The 0.85 exponent instead of 0.66 can improve the prediction accuracy of the NDF indigestible fraction from lignin content

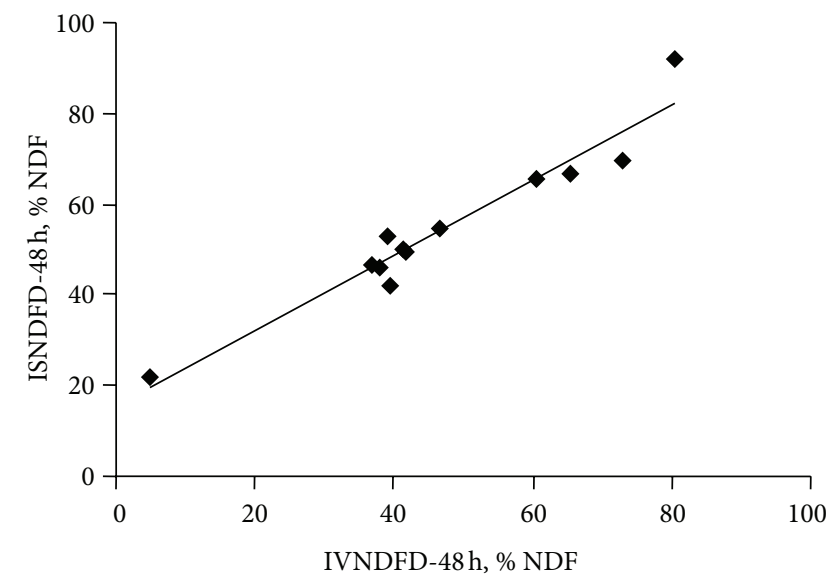

FIgURE 1: Relationship between the in vitro $(X)$ and the in situ $(Y)$ degradability of NDF. $Y=0.8313 X+15.475 . R^{2}=0.94$.

$[2,13]$. Therefore in tropical feed, the restrictive effect of lignin in NDF degradation is less intense than that proposed by the law of surface [2].

Advantageously, the in vitro fermentation can include the impact of factors other than lignin on ruminal fiber degradation, for example, effects of nonstructural carbohydrate, fat, silica, or cutin [11, 44]. Furthermore, it is difficult to get accurate values of lignin by gravimetric analyses, since lignin values varies depending on the analytical method used [45].

The NRC (2001) [3] suggests using IVdNDF values to replace the use of lignin in the calculation of TDN. Similarly, Shaver [8] used IVdNDF in a summative equation to calculate the $\mathrm{EN}_{L}$ value corn (Zea mays) silage. Using bovine rumen fluid, Lundberg et al. [39] compared the values of predicted TDN based on IVdNDF versus in vitro digestible organic matter (IVdOM) values as acceptable predictors of in vivo OM digestibility in cattle. In that study, IVdNDF explained $98 \%$ of the observed variability in IVdOM values of corn silage. 
TABLE 4: Predicted TDN values (\%) from summative models.

\begin{tabular}{|c|c|c|c|c|c|}
\hline Feed & LSdNDF & 0,75IVdNDF & IVdNDF & ISdNDF & Rocha-Junior \\
\hline Discarded corn & 57.7 & 58.8 & 67.5 & 70.2 & 58.3 \\
\hline Discarded sorghum & 62.7 & 59.3 & 63.6 & 69.6 & 638 \\
\hline Discarded sesame & 61.7 & 53.1 & 53.5 & 59.2 & 62.8 \\
\hline Citrus pulp & 71.3 & 78.8 & 84.0 & 87.0 & 72.4 \\
\hline Sugar cane, whole plant, 6 months & 56.8 & 45.4 & 52.1 & 56.9 & 56.9 \\
\hline Forage sorghum & 48.3 & 38.9 & 45.6 & 47.6 & 49.4 \\
\hline Bermudagrass & 46.7 & 31.7 & 39.8 & 46.6 & 46.1 \\
\hline Brachiaria & 49.6 & 35.5 & 42.6 & 50.0 & 50.2 \\
\hline King grass & 52.5 & 35.1 & 42.1 & 48.0 & 51.7 \\
\hline Kikuyu grass & 41.6 & 32.9 & 41.5 & 47.3 & 42.0 \\
\hline Guinea grass & 45.2 & 48.9 & 60.7 & 61.5 & 45.9 \\
\hline Stargrass, 20 days & 52.2 & 57.9 & 70.7 & 68.6 & 52.0 \\
\hline
\end{tabular}

TABLE 5: Effect of the TDN prediction model on the relationship between TDN predicted value and the observed value of IVTDMD at $48 \mathrm{~h}$.

\begin{tabular}{lccc}
\hline Model & Intercept & Slope & $R^{2}$ \\
\hline LSdNDF & +25.543 & 0.4183 & 0.41 \\
0,75IVdNDF & -22.009 & 1.0362 & 0.90 \\
IVdNDF & -16.169 & 1.0576 & 0.96 \\
ISdNDF & -3.246 & 0.9254 & 0.91 \\
Rocha-Junior & +24.606 & 0.4391 & 0.42 \\
\hline
\end{tabular}

TABLE 6: Calculated TDN values at maintenance conditions using equation IVdNDF from NRC [3] and its conversion to ME values at production levels.

\begin{tabular}{lccc}
\hline Feed & $\begin{array}{c}\mathrm{TDN}_{1 X} \\
\%\end{array}$ & $\begin{array}{c}\mathrm{TDN}_{3 X} \\
\%\end{array}$ & $\begin{array}{c}\mathrm{ME}_{3 X} \\
\mathrm{Mcal}^{2} \mathrm{~kg} \mathrm{DM}\end{array}$ \\
\hline Discarded corn & 67.5 & 63.8 & 2.4 \\
Discarded sorghum & 63.6 & 61.3 & 2.2 \\
Discarded sesame & 53.5 & 535 & 1.9 \\
Citrus pulp & 84.0 & 74.4 & 2.8 \\
Sugar cane, whole plant, 6 months & 52.1 & 52.1 & 1.8 \\
Forage sorghum & 45.6 & 45.6 & 1.5 \\
Bermudagrass & 39.8 & 39.8 & 1.3 \\
Brachiaria & 42.6 & 42.6 & 1.4 \\
King grass & 42.1 & 42.1 & 1.4 \\
Kikuyu grass & 41.5 & 41.5 & 1.4 \\
Guinea grass & 60.7 & 59.4 & 2.2 \\
Stargrass, 20 days & 70.7 & 65.9 & 2.5 \\
\hline
\end{tabular}

If $\mathrm{TDN}_{1 X}<60 \%: \mathrm{TDN}_{3 X}=\mathrm{TDN}_{1 X}$. If $\mathrm{TDN}_{1 X}>60 \%: \mathrm{TDN}_{3 X}=\mathrm{TDN}_{1 X}-$ $\left(0.18 * \mathrm{TDN}_{1 X}-10.3\right) * 2 . \mathrm{ME}_{3 X}, \mathrm{Mcal} / \mathrm{kg}=0.036 \times \mathrm{TDN}_{3 X}$.

The in situ degradability technique for determining dNDF has also been used in the calculation of TDN and other energy systems values for dairy cows [33].

The results of the present study also suggest that the 0.75 coefficient used for dNDF in the NRC [3] equation is inappropriate as noted by several researchers $[12,17]$. Similarly, the adjusted coefficients for dNDF according Rocha-Junior et al. [25] were inappropriate.

3.4. Energy Calculations at Production Levels. By definition, TDN corresponds to ingestion levels of maintenance $\left(\mathrm{NDT}_{1 X}\right)$ but Sutton and Alderman [18] indicate that highproducing lactating goats can reach intakes equivalent to 3 to 4 times maintenance needs. Therefore, both the digestibility and TDN value of the diet is reduced. In dairy cows, the digestibility of good quality diets is reduced by approximately $8 \%$ when the DM intake levels reach up to three times the maintenance needs [3]. Therefore, the values of TDN in lactating goats, with intakes of up to 3 times the maintenance level $\left(\mathrm{NDT}_{3 X}\right)$, can be estimated in mixed diets following the NRC procedure for dairy cows [3] as follows.

$$
\begin{aligned}
& \text { If } \mathrm{TDN}_{1 X}<60 \%: \mathrm{TDN}_{3 X}=\mathrm{TDN}_{1 X} \\
& \text { If } \mathrm{TDN}_{1 X}>60 \%: \mathrm{TDN}_{3 X}=\mathrm{TDN}_{1 X}-(0.18 * \\
& \left.\mathrm{TDN}_{1 X}-10.3\right) * 2 .
\end{aligned}
$$

In turn, the concentration of ME at production levels (3 times the maintenance level) could be calculated using the following standard equations [46]:

$$
\mathrm{ME}_{3 X}, \mathrm{Mcal} / \mathrm{kg}=0.036 \times \mathrm{TDN}_{3 X} .
$$

Table 6 shows the conversion of $\mathrm{TDN}_{1 X}$ values, calculated using IVdNDF into ME values at production levels.

\section{Conclusions}

In general, values of IVTDMD at $48 \mathrm{~h}$ were higher than ISDMD, except for citrus pulp. In forages, IVTDMD had a rank (51.4 to $80.8 \%$ ) greater than in byproducts (68.1 to $94.9 \%)$. Values for ISNDFD and IVNDFD at $48 \mathrm{~h}$ were highly correlated $(r=0.94)$. The NDF of discarded sesame was highly indigestible. The TDN values predicted by the NRC model, exclusively based on chemical composition, explained only $41 \%$ of the observed variability in IVTDMD values; therefore, they were less successful than those predicted by models incorporating dNDF determined by either in vitro or in situ digestibility. In vitro NDF digestibility is 
an acceptable method to estimate the dNDF fraction in summative equations. However, the more accurate model was that where the value of $\mathrm{dNDF}$ is used with a coefficient equal to 1 .

\section{Acknowledgment}

This research was in part supported by the Research Council at the Universidad Centroccidental Lisandro Alvarado, Venezuela.

\section{References}

[1] Alimentación de Bovinos, Ovinos y Caprinos: Necesidades de los Animales, Valores de los Alimentos, Editorial Acribia, Zaragoza, España, 2010.

[2] Commonwealth Scientific and Industrial Research Organization, Nutrient Requirements of Domesticated Ruminants, CSIRO Publishing, Collingwood, Australia, 2007.

[3] National Research Council (NRC2001), Nutrient Requirements of Dairy Cattle, The National Academies Press, Washington, DC, USA, 7th edition, 2001.

[4] National Research Council (NRC2007), Nutrient Requirements of Small Ruminants: Sheep, Goats, Cervids, and New World Camelids, The National Academies Press, Washington, DC, USA, 2007.

[5] K. A. Beauchemin, "Using ADF and NDF in dairy cattle diet formulation-a western Canadian perspective," Animal Feed Science and Technology, vol. 58, no. 1-2, pp. 101-111, 1996.

[6] J. D. Donker, "Improved energy prediction equations for dairy cattle rations," Journal of Dairy Science, vol. 72, no. 11, pp. 29422948, 1989.

[7] D. W. Harlan, J. B. Holter, and H. H. Hayes, "Detergent fiber traits to predict productive energy of forages fed free choice to nonlactating dairy cattle," Journal of Dairy Science, vol. 74, no. 4, pp. 1337-1353, 1991.

[8] R. D. Shaver, "Practical application of fiber and starch digestibility in dairy cattle nutrition," in Cornell Nutrition Conference for Feed Manufacturers, p. 41, Syracuse, New York, NY, USA, 2002.

[9] W. P. Weiss, H. R. Conrad, and N. R. S. Pierre, "A theoreticallybased model for predicting total digestible nutrient values of forages and concentrates," Animal Feed Science and Technology, vol. 39, no. 1-2, pp. 95-110, 1992.

[10] H. R. Conrad, W. P. Weiss, W. O. Odwongon, and W. L. Shockey, "Estimating net energy of lactation from components of cell solubles and cell walls," Journal of Dairy Science, vol. 67, no. 2, pp. 427-436, 1984.

[11] G. Dryden, "Physico-chemical composition and digestibility of forages and cereal grains," in Animal Nutrition Science, pp. 4056, CABI, Wallingford, UK, 1st edition, 2008.

[12] E. Detmann, S. C. Valadares, D. S. Pina et al., "Prediction of the energy value of cattle diets based on the chemical composition of the feeds under tropical conditions," Animal Feed Science and Technology, vol. 143, pp. 127-147, 2008.

[13] S. W. Coleman, S. P. Hart, and T. Sahlu, "Relationships among forage chemistry, rumination and retention time with intake and digestibility of hay by goats," Small Ruminant Research, vol. 50, no. 1-2, pp. 129-140, 2003.

[14] L. Bava, L. Rapetti, G. M. Crovetto et al., "Effects of a nonforage diet on milk production, energy, and nitrogen metabolism in dairy goats throughout lactation," Journal of Dairy Science, vol. 84, no. 11, pp. 2450-2459, 2001.

[15] S. Carvalho, M. T. Rodrigues, R. H. Branco, C. Aparecida, and F. Rodriguez, "Consumo de nutrientes, produção e composição do leite de cabras da raça Alpina alimentadas com dietas contendo diferentes teores de fibra," The Sociedade Brasileira de Zootecnia, vol. 35, pp. 1154-1161, 2006.

[16] C. D. Lu, J. R. Kawas, and O. G. Mahgoub, "Fibre digestión and utilization in goats," Small Ruminant Research, vol. 60, pp. 4552, 2005.

[17] R. L. Reid, G. A. Jung, J. M. Cox-Ganser, B. F. Rybeck, and E. C. Townsend, "Comparative utilization of warm- and cool-season forages by cattle, sheep and goats," Journal of Animal Science, vol. 68, no. 9, pp. 2986-2994, 1990.

[18] J. D. Sutton and G. Alderman, "The energy and protein requirements of pregnant and lactating dairy goats: The Agriculture and Food Research Council report," Livestock Production Science, vol. 64, no. 1, pp. 3-8, 2000.

[19] Association Of Official Analytical Chemists, Official Methods of Analysis, AOAC, Arlington, Va, USA, 15th edition, 1990.

[20] J. E. Nocek, "Novel method for quantitating structural and nonstructural carbohydrates in feedstuffs (Inventor)," US Patent no. 4617276, October 1986.

[21] G. Licitra, T. M. Hernandez, and P. J. Van Soest, "Standardization of procedures for nitrogen fractionation of ruminant feeds," Animal Feed Science and Technology, vol. 57, no. 4, pp. 347-358, 1996.

[22] P. J. Van Soest, J. B. Robertson, and B. A. Lewis, "Methods for dietary fiber, neutral detergent fiber, and nonstarch polysaccharides in relation to animal nutrition," Journal of Dairy Science, vol. 74, no. 10, pp. 3583-3597, 1991.

[23] R. Holmbak-Petersen, C. Tobía, O. Rosendo et al., "Experiencia con cánulas ruminales de plastisol para bovinos," Gaceta de Ciencias Veterinarias, vol. 12, pp. 67-71, 2007.

[24] P. J. Van Soest, R. H. Wine, and L. A. Moore, "Estimation of the true digestibility of forages by the in vitro digestion of cell walls," in Proceedings of the 10th International Grassland Congress, p. 438, Finish Grassland Association, Helsinki, Finland, 1966.

[25] V. Rocha-Junior, S. D. C. Valadares Filho, M. Borges et al., "Estimative of energy value of feed and validation of equations proposed by NRC (2001)," Revista Brasileira de Zootecnia, vol. 32, no. 2, pp. 480-490, 2003.

[26] D. R. Mertens, "Gravimetric determination of amylase-treated neutral detergent fiber in feeds with refluxing in beakers or crucibles: collaborative study," Journal of AOAC International, vol. 85, no. 6, pp. 1217-1240, 2002.

[27] O. Bochi-Brum, M. D. Carro, C. Valdes, J. S. Gonzalez, and S. López, "Digestibilidad in vitro de forrajes y concentrados: efecto de la ración de los animales donantes de liquido ruminal," Archivos de Zootecnia, vol. 48, pp. 51-61, 1999.

[28] E. M. Alcaide, A. I. M. García, and J. F. A. Aguilera, "A comparative study of nutrient digestibility, kinetics of degradation and passage and rumen fermentation pattern in goats and sheep offered good quality diets," Livestock Production Science, vol. 64, no. 2-3, pp. 215-223, 2000.

[29] M. D. Isac, M. A. García, J. F. Aguilera, and E. Molina Alcaide, "A comparative study of nutrient digestibility, kinetics of digestion and passage and rumen fermentation pattern in goats and sheep offered medium quality forages at the maintenance level of feeding," Archiv fur Tierernahrung, vol. 46, no. 1, pp. 37-50, 1994. 
[30] A. G. Silva, R. C. Wanderley, A. F. Pedroso, and G. Ashbell, "Ruminai digestion kinetics of citrus peel," Animal Feed Science and Technology, vol. 68, no. 3-4, pp. 247-257, 1997.

[31] L. Ortega and B. Gonzalez, "Efecto de la fertilización nitrogenada y frecuencia de corte sobre los rendimientos de materia seca y valor nutritivo del pasto estrella (Cynodon nlemfuensis)," Revista de la Facultad de Agronomía LUZ, vol. 7, pp. 217-228, 1990.

[32] S. J. Mabjeesh, M. Cohen, and A. Arieli, "In vitro methods for measuring the dry matter digestibility of ruminant feedstuffs: comparison of methods and inoculum source," Journal of Dairy Science, vol. 83, no. 10, pp. 2289-2294, 2000.

[33] J. L. Beckman and W. P. Weiss, "Nutrient digestibility of diets with different fiber to starch ratios when fed to lactating dairy cows," Journal of Dairy Science, vol. 88, no. 3, pp. 1015-1023, 2005.

[34] J. Rojas, M. I. De Chávez, and R. Fernández, "Capacidad comparativa de digestión entre ovinos y caninos," Zootecnia Tropical, vol. 2, pp. 20-29, 1984.

[35] F. Suarez, Digestibilidad aparente del pasto mulato II (Brachiaria híbrido) en cabras y ovejas [Ph.D. thesis], Zamorano. Carrera de Ciencia y Producción Agropecuaria, Zamorano, Honduras, 2007.

[36] M. Spanghero, S. Boccalon, L. Gracco, and L. Gruber, "NDF degradability of hays measured in situ and in vitro," Animal Feed Science and Technology, vol. 104, no. 1-4, pp. 201-208, 2003.

[37] P. H. Robinson, M. C. Mathews, and J. G. Fadel, "Influence of storage time and temperature on in vitro digestion of neutral detergent fibre at $48 \mathrm{~h}$, and comparison to $48 \mathrm{~h}$ in sacco neutral detergent fibre digestion," Animal Feed Science and Technology, vol. 80, no. 3-4, pp. 257-266, 1999.

[38] W. E. Kunkle and D. B. Bates, "Evaluating feed purchasing options: Energy, protein, and mineral supplements," in Proceedings of the 47th Annual Florida Beef Cattle Short Course Proceedings, p. 59, Gainesville, Fla, USA, 1998.

[39] K. Lundberg, P. Hoffman, L. Bauman, and P. Berzaghi, "Prediction of forage energy content by near infrared spectroscopy and summative equations," The Professional Animal Scientist, vol. 20, pp. 262-269, 2004.

[40] J. M. A. Tilley and R. A. Terry, "A two-stage technique for the in vitro digestion of forage crops," The Journal of the British Grassland Society, vol. 18, p. 104, 1963.

[41] J. F. Ayres, "Sources of errors with in vitro digestibility assay of pasture feeds," Grass and Forage Science, vol. 46, no. 1, pp. 89-97, 1991.

[42] K. A. Magalhães, S. C. Valadares Filho, E. Detmann et al., "Evaluation of indirect methods to estimate the nutritional value of tropical feeds for ruminants," Animal Feed Science and Technology, vol. 155, no. 1, pp. 44-54, 2010.

[43] D. R. Mertens, "Fiber: measuring, modeling and feeding," in Proceedings of the Cornell Nutrition Conference for Feed Manufacturers, p. 1, Syracuse, New York, NY, USA, 2002.

[44] S. G. Haddad and R. J. Grant, "Influence of nonfiber carbohydrate concentration on forage fiber digestion in vitro," Animal Feed Science and Technology, vol. 86, no. 1-2, pp. 107-115, 2000.

[45] H. J. G. Jung, "Analysis of forage fiber and cell walls in ruminant nutrition," Journal of Nutrition, vol. 127, no. 5, pp. 810S-813S, 1997.

[46] National Research Council (NRC1981), Nutrient Requirements of Goats, The National Academies Press, Washington, DC, USA, 1981. 

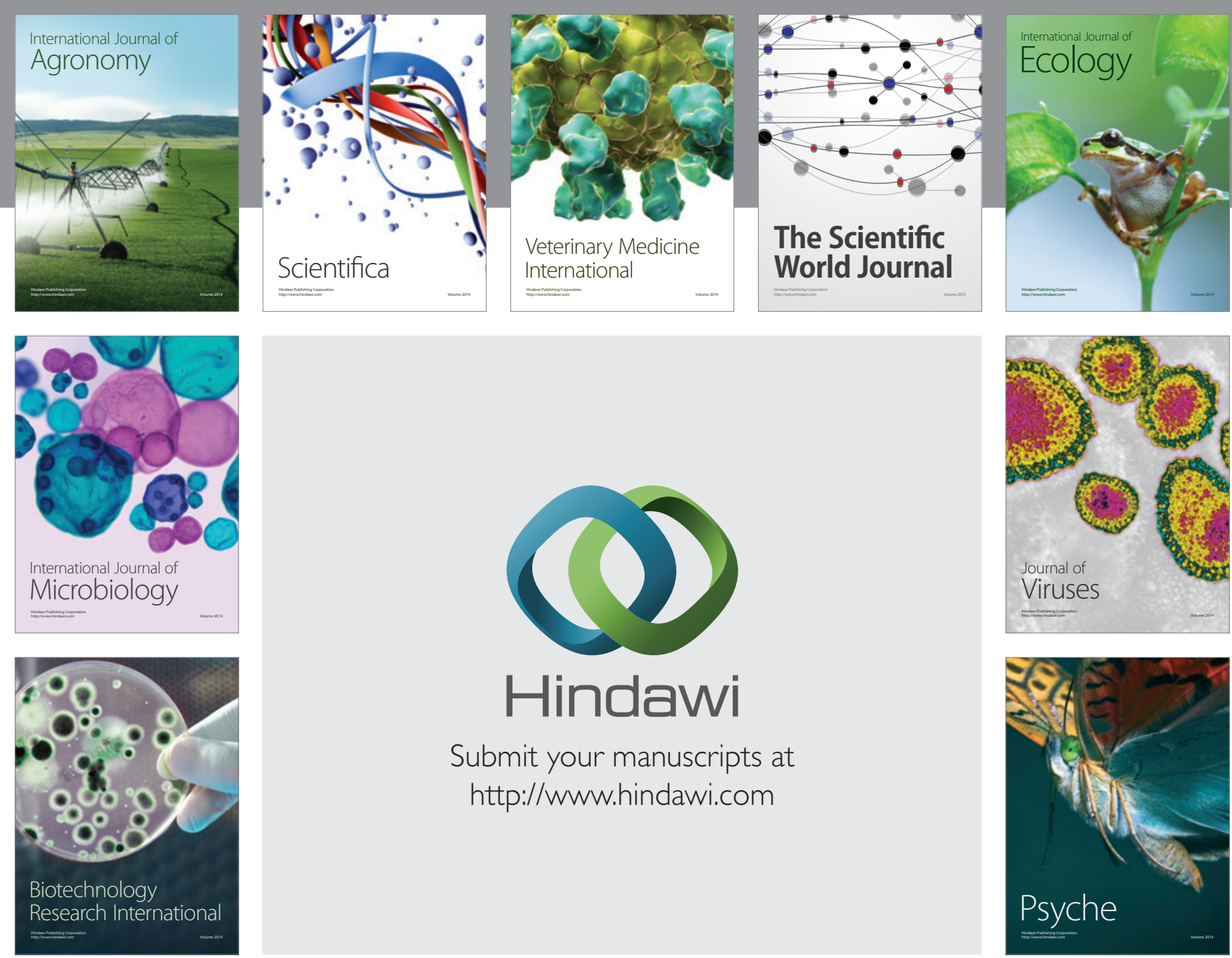

Submit your manuscripts at http://www.hindawi.com
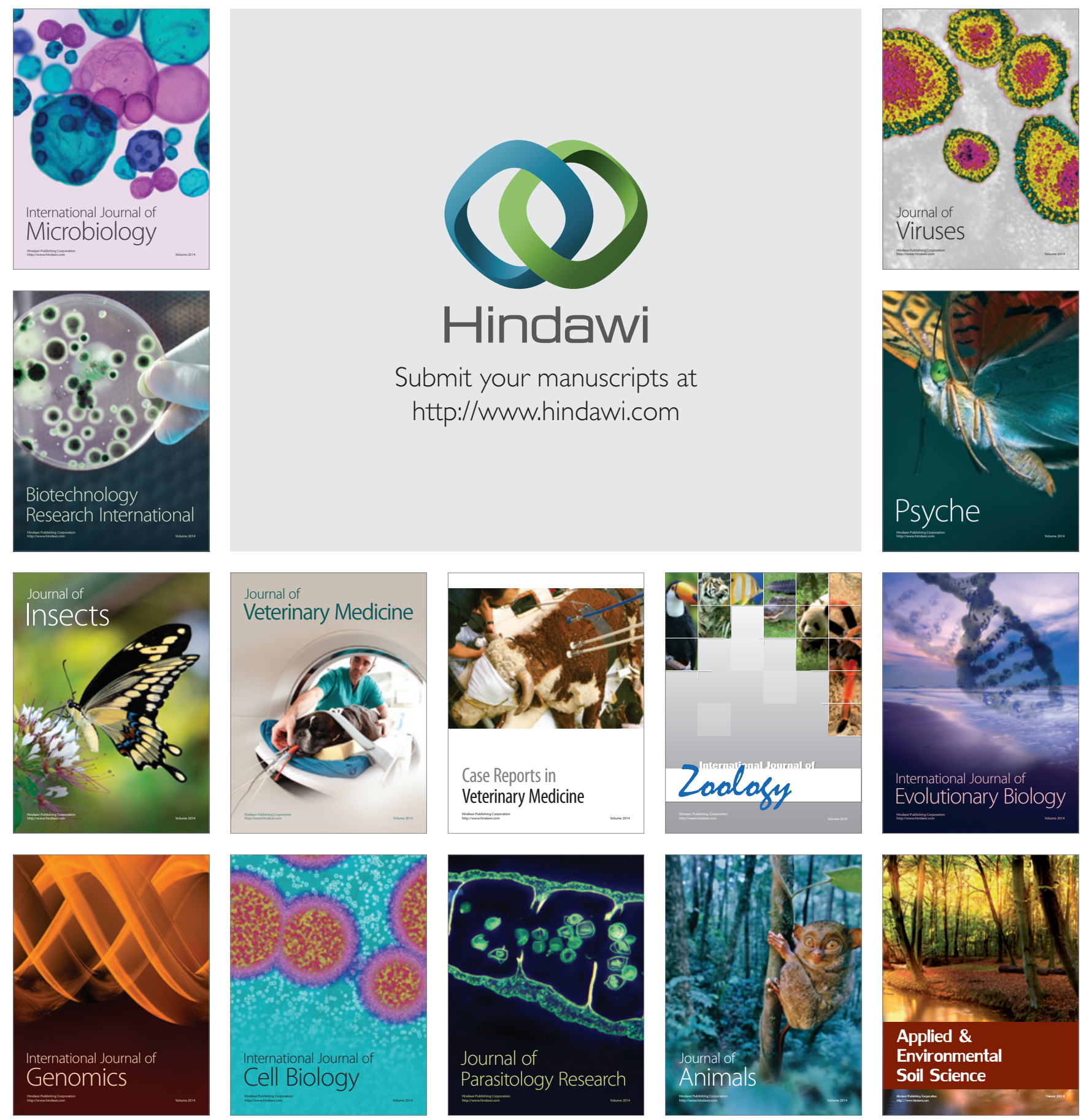